\title{
Effect of compound feed acidification on the body weight gain of quails on mini-farms
}

\author{
Alexey Trifanov ${ }^{1}$, Evgeny Tikhonov $^{2}$, Valentin Bazykin ${ }^{1, *}$ \\ ${ }^{1}$ Federal Scientific Agroengineering Centre VIM, 3, Fil'trovskoye sh., 196625, pos. Tyarlevo, Saint- \\ Petersburg, Russia \\ ${ }^{2}$ Petrozavodsk State University, 33, pr. Lenina, 185910, Petrozavodsk, Russia
}

\begin{abstract}
The article presents the study results on the fattening effectiveness of Texas Broiler quails using the formulated feed with "B.I.O. Acid Ultra" acidifier. Space and layout design of the mini-farm allowed to house 1000 head of the main flock and up to 300 young birds. The inside climate system of the mini-farm maintained the temperature in the range of $18{ }^{\circ} \mathrm{C}-20{ }^{\circ} \mathrm{C}$ and $75 \%$ humidity. In the study, 250 head of daily chicks were randomly selected and divided into 5 groups of 50 head each - one control group and four experimental ones. The study lasted for 8 weeks, i.e. the meat quail fattening period. The addition of the acidifier to the diet in the amount of $0.23 \%$ was found to result in $9.0 \%$ increase in the bodyweight of the 8 -week old quails. The average daily weight increments also increased during the entire fattening period. The use of the acidifier reduced the feed conversion ratio by $4.1 \%-6.79$ versus 7.1 in the control group. However, the effect of different acidifiers on the effectiveness of quail fattening and the organoleptic and other quality indicators of the quail meat requires further comparative inquiry.
\end{abstract}

\section{Introduction}

Currently, the use of antibiotics in poultry farming for microbiological process control is increasingly considered as a negative practice that deteriorates the final product quality $[1,2]$. Various additives - phytobiotics, prebiotics, probiotics, acidifiers, etc., are proposed as an alternative, including to enhance productivity [3]. Acidifiers are one of the most common feed additives in industrial-scale poultry farming. They are based on organic acids and their salts.

The highly acidic environment of the stomach contributes to the abundant secretion of gastric juice and pancreatic enzymes. These are the main factors for efficient food digestion and nutrient intake. The presence of various bacteria in the stomach harms digestion as they reduce the useful nutrient intake area. The organic acids from acidifiers increase the stomach $\mathrm{pH}$ providing a bactericidal effect. By reducing the bacterial content on the stomach walls, the acidifiers boost animal productivity. The use of feed acidifiers as natural productivity promoters is one of the promising trends in the development of environmentally-friendly farming [4].

\footnotetext{
${ }^{*}$ Corresponding author: valentin-bazykin@mail.ru
} 
Overview of recent research and publications shows that many relevant organizations around the world address the application of organic acids as animal feed acidifiers $[5,6]$. According to investigations, the organic acids promote the microflora formation in the early stages of chicks' development that positively affects their health and growth rate. Also, organic acids effectively regulate the number of bacteria. For example, they have an antibacterial effect on Salmonella and Campylobacter. The lipophilicity of organic acids allows them to pass across the bacterial cell membrane into the cytoplasm and acidify it. This explains the fact that even under the long-term exposure to organic acids, the adaptation mechanism of bacteria to antibacterial agents fails [7].

Many studies prove that organic acids in animal nutrition contribute to better feed conversion and more intensive growth through the improved digestibility and nutrients intake [8-10]. Besides, acidifiers have an antioxidant and neurotrophic effect. They enhance the general physiological state of animals and accelerate the biosynthesis $[11,12]$.

Currently, the search for the most effective formulations and acidifier application techniques is an urgent issue in poultry farming. Various organic acids combined in one acidifier can provide a complex effect at different acidity levels along the whole digestive tract of birds. Besides, the biochemical processes of nutrients intake vary significantly with the birds' age and gender. Therefore, the required specific acidifier amount and its formulation need to be determined in the first place to ensure the most beneficial effect on the digestive processes in quails in different growth periods. This will improve the conversion of nutrient and biologically active feed substances into the final products of quailing - meat and eggs.

The study objective was to estimate the efficiency of feeds with the addition of a multicomponent dry acidifier in young quail fattening.

\section{Material and methods}

The study object was the Texas Broiler quails. The study plan was based on the method of mass-balanced groups in an experimental quail mini-farm of Petrozavodsk State University.

Space and layout design of the mini-farm is shown on Fig.1

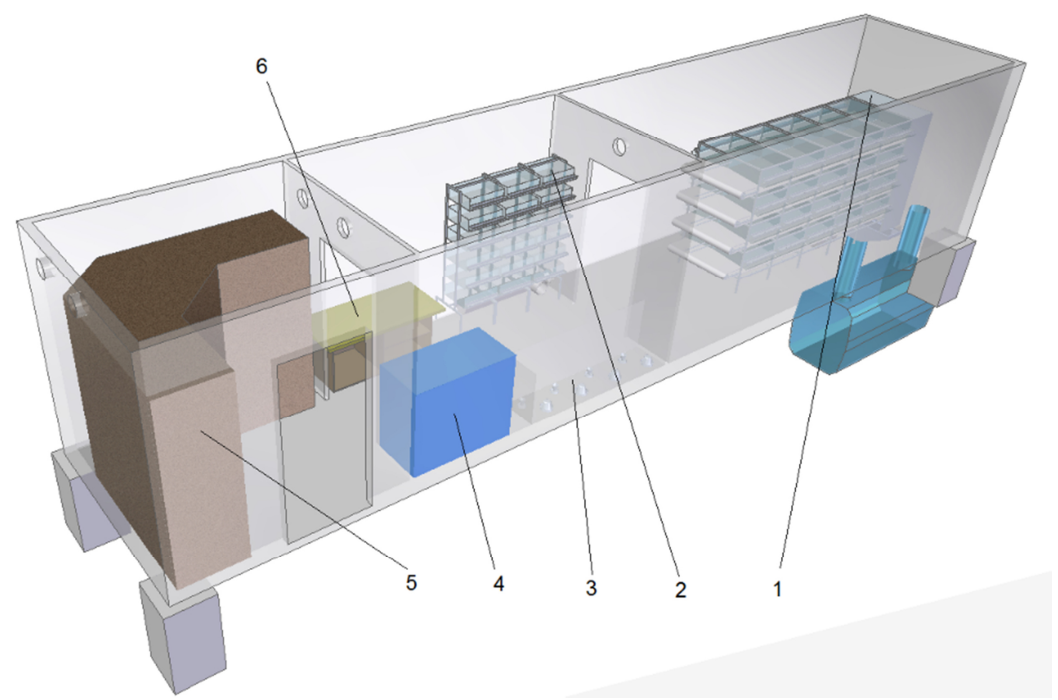

Fig. 1. Quail growing mini-farm. Where: 1 - OKP-4 cage battery; 2 - cage battery for young quails; 3 - a battery with 5 brooders, trough feeders, drinkers and infra-red lamps; 4 - Fiem Cosmo 72 analogue automatic incubator; 5 - feed storing box; 6 - work bench. 
Space and layout design of the mini-farm allowed to house 1000 head of the main flock and up to 300 young birds. The availability of an incubator and brooders provided for a full rearing cycle in case the brood-stock is in place.

The inside climate system of the mini-farm maintained the temperature in the range of $18{ }^{\circ} \mathrm{C}-20{ }^{\circ} \mathrm{C}$ and $75 \%$ humidity. A regenerative heat exchanger within the supply and exhaust ventilation system ensured the energy efficiency (Fig.2).

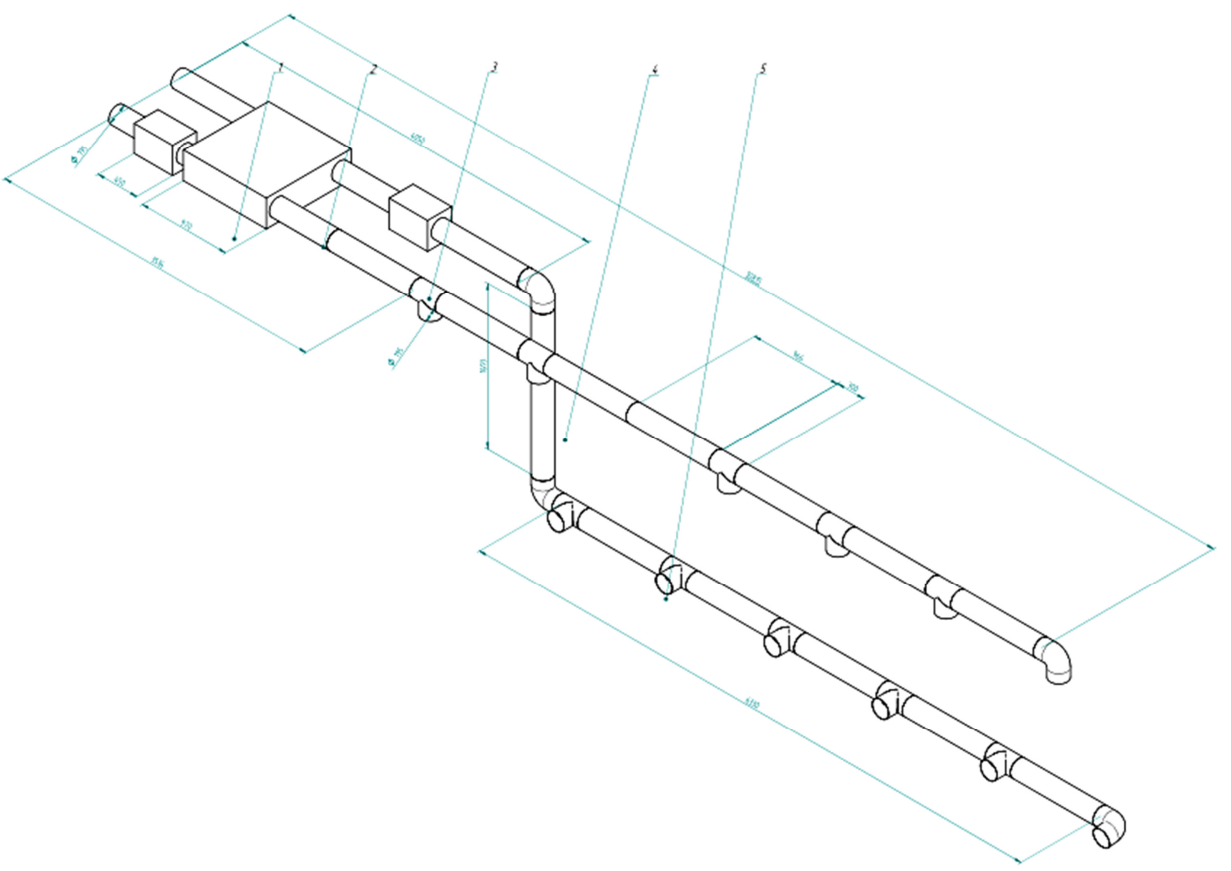

Fig. 2. Arrangement of ventilation system elements. Where: 1 - regenerative heat exchanger; 2 supply air duct; 3 - supply ceiling air diffuser (anemostat); 4 - exhaust air duct; 5 - exhaust ceiling air diffuser (anemostat).

In the study, 250 head of daily chicks were randomly selected and divided into 5 groups of 50 head each - one control group and four experimental ones. Males and females were redistributed to ensure equal proportions in all groups. The study lasted for 8 weeks, i.e. the meat quail-fattening period. The young quail flock was housed in identical brooders in the same room at the mini-farm. The watering of quails was provided by nipple drinkers joined in a single watering system, five drinkers per brooder. The temperature and humidity parameters in the brooders were in line with the established standards.

The B.I.O. Acid Ultra feed additive was used as an acidifier with the following composition: formic acid, ammonium formate, propionic acid, ammonium propionate and lactic acid [13].

The study plant is shown in Table 1.

Table 1. The study plan.

\begin{tabular}{|l|c|c|}
\hline \multicolumn{1}{|c|}{ Group } & Number of head & $\begin{array}{c}\text { Acidifier content in the } \\
\text { formulated feed, } \%\end{array}$ \\
\hline Control group & 50 & 0 \\
\hline Experimental group 1 & 50 & 0.1 \\
\hline Experimental group 2 & 50 & 0.23 \\
\hline Experimental group 3 & 50 & 0.48 \\
\hline Experimental group 4 & 50 & 0.6 \\
\hline
\end{tabular}


The quails were fed ad lib with PK 1-2-40777/504 complete high-protein feed manufactured by Kirov Feed Factory (Saint Petersburg). The acidifier was added to the feed by multi-stage mixing. Every day the following parameters were determined (measured): mortality, live weight gain, feed consumption, feed conversion. The study results were processed by Statistica package.

\section{Results and discussion}

The study demonstrated the dependence of the quail live weight on the content of dry fivecomponent acidifier in the feed. The results are presented in Table 2.

Table 2. Live weight of quails, g.

\begin{tabular}{|c|c|c|c|c|c|c|c|c|c|c|}
\hline Week & 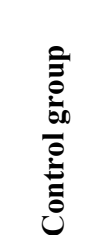 & 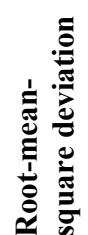 & 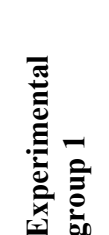 & 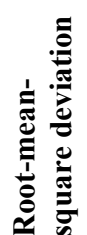 & 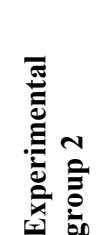 & 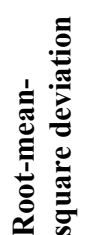 & 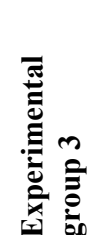 & 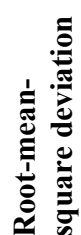 & 窇 & 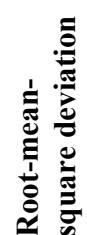 \\
\hline 0 & 8.19 & 0.08 & 8.09 & 0.08 & 7.98 & 0.08 & 8.30 & 0.08 & 8.12 & 0.08 \\
\hline 1 & 27.30 & 0.54 & 27.51 & 0.51 & 27.51 & 0.55 & 28.25 & 0.56 & 27.76 & 0.54 \\
\hline 2 & 65.73 & 0.96 & 66.99 & 0.99 & 69.83 & 1.05 & 68.67 & 1.05 & 68.50 & 1.03 \\
\hline 3 & 113.93 & 1.65 & 115.29 & 1.70 & 121.91 & 1.80 & 119.39 & 1.82 & 118.86 & 1.77 \\
\hline 4 & 167.58 & 1.94 & 169.16 & 1.88 & 177.77 & 2.12 & 173.99 & 2.17 & 173.64 & 2.06 \\
\hline 5 & 213.26 & 3.19 & 216.62 & 3.14 & 227.54 & 3.28 & 223.13 & 3.17 & 222.43 & 3.20 \\
\hline 6 & 250.95 & 4.99 & 256.20 & 5.45 & 271.53 & 5.13 & 265.44 & 5.37 & 264.39 & 5.32 \\
\hline 7 & 270.38 & 6.14 & 276.99 & 6.43 & 295.89 & 6.62 & 288.75 & 6.28 & 287.21 & 6.44 \\
\hline 8 & 284.03 & 7.46 & 290.64 & 7.74 & 309.54 & 7.93 & 302.40 & 7.59 & 300.86 & 7.75 \\
\hline
\end{tabular}

At the initial stage of the study, no statistically significant difference in the experimental groups was observed compared with the control group. Subsequently, Experimental group 2 , which was fed with the formulated feed with $0.23 \%$ acidifier content, showed the best indicators of the live weight gain. The live weight of quails in this group statistically exceeded that of other groups during the period from week 2 to week 8 of the study. The difference in this indicator ranged from 0.8 to $9.0 \%$ against the control group. The live weight gain of other experimental groups also reliably exceeded that of the control group.

The average daily live weight increments demonstrated the same tendency as shown on Fig. 3 by groups. 


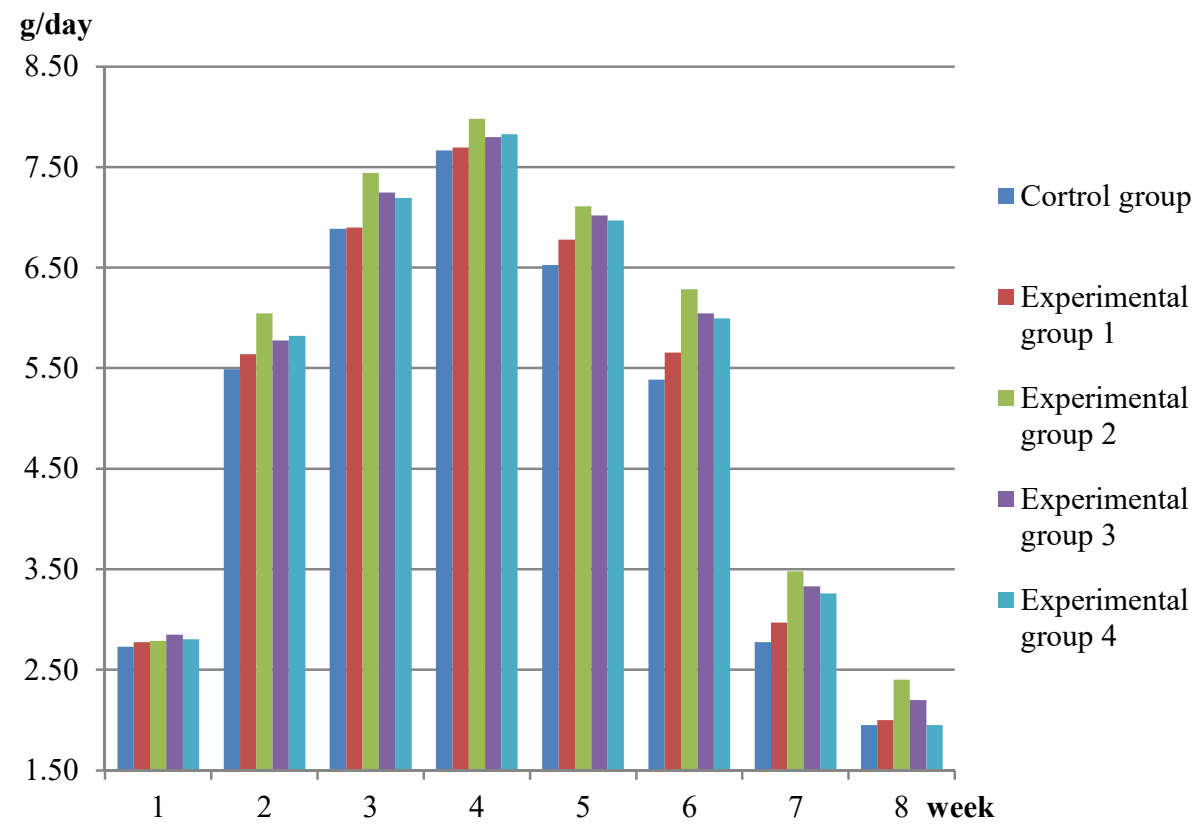

Fig. 3. Dynamics of average daily live weight increments by weeks.

Analysis of feed consumption showed that the use of an acidifier affected the specific feed inputs. The results are presented in Table 3.

Table 3. Feed consumption per $1 \mathrm{~kg}$ of live weight gain, $\mathrm{kg}$.

\begin{tabular}{|c|c|c|c|c|c|}
\hline Week & $\begin{array}{c}\text { Control } \\
\text { group }\end{array}$ & $\begin{array}{c}\text { Experimental } \\
\text { group 1 }\end{array}$ & $\begin{array}{c}\text { Experimental } \\
\text { group 2 }\end{array}$ & $\begin{array}{c}\text { Experimental } \\
\text { group 3 }\end{array}$ & $\begin{array}{c}\text { Experimental } \\
\text { group 4 }\end{array}$ \\
\hline 1 & 2.12 & 2.09 & 2.04 & 2.06 & 2.08 \\
\hline 2 & 2.82 & 2.76 & 2.69 & 2.74 & 2.75 \\
\hline 3 & 4.22 & 4.18 & 4.08 & 4.12 & 4.15 \\
\hline 4 & 4.47 & 4.45 & 4.31 & 4.38 & 4.40 \\
\hline 5 & 5.98 & 5.84 & 5.55 & 5.72 & 5.77 \\
\hline 6 & 11.70 & 11.63 & 10.61 & 11.12 & 11.27 \\
\hline 7 & 18.72 & 18.10 & 17.43 & 17.72 & 17.99 \\
\hline 8 & 24.93 & 24.68 & 24.01 & 24.31 & 24.58 \\
\hline
\end{tabular}

According to Table 3, the quails in Experimental group 2 consumed the least amount of feed per $1 \mathrm{~kg}$ of live weight gain compared with the Control group and other experimental groups.

\section{Conclusions}

The study results prove the applicability of a feed acidifier in Texas Broiler quails fattening. The most effective concentration of B.I.O. Acid Ultra acidifier was $0.23 \%$ of the total feed. 
It allowed increasing the live weight by $9 \%$ at the end of the quail-fattening period. At the same time, the feed inputs per $1 \mathrm{~kg}$ of live weight gain were $4.1 \%$ lower. The feed conversion ratio when using the acidifier was 6.79 versus 7.1 in the control group.

In this study, a special acidifier brand was used. At the same time, there are other manufacturers and formulations [14]. The effect of different acidifiers on the effectiveness of quail fattening and the organoleptic and other quality indicators of the quail meat requires further comparative inquiry.

\section{References}

1. V. Furtula, E.G. Farrell, F. Diarrassouba, H. Rempel, M.S. Diarra, Poultry Science 89, 180-188 (2010) https://doi.org/10.3382/ps.2009-00198

2. M. Pesciaroli, C. Francesca Magistrali, G. Filippini, E. Maria Epifanio, G. Pezzotti, International Journal of Food Microbiology 3142, 108391 (2020) https://doi.org/10.1016/j.ijfoodmicro.2019.108391

3. W.H. Kim, H.S. Lillehoj, Animal Feed Science and Technology 250, 41-50 (2019) https://doi.org/10.1016/j.anifeedsci.2018.09.016

4. H. Hamid, H.Q. Shi, G.Y. Ma, Y Fan, W.X. Li, L.H. Zhao, J.Y. Zhang, C Ji, Q.G. Ma, Poultry Science 97, 3601-3609 (2018) https://doi.org/10.3382/ps/pey212

5. A. Eftekhari, V. Rezaeipour, R. Abdullahpour, Livestock Science 180, 158-163 (2015) https://doi.org/10.1016/j.livsci.2015.07.010

6. A. Vohra, P. Syal, A. Madan, Animal Feed Science and Technology 219, 31-47 (2016) https://doi.org/10.1016/j.anifeedsci.2016.05.019

7. S.K. Gupta, S. Kataki, S. Chatterjee, R.K. Prasad, D.K. Gupta, Journal of Cleaner Production, 120351 (2020) https://doi.org/10.1016/j.jclepro.2020.120351

8. G. da Costa Caetano, R. Reis Mota, D. Alvesda Silva, H. Rojasde Oliveira, J. Marcelo Soriano Viana, O. Henrique G.B.D.de Siqueira, P. Henrique F. Freitas, F. Fonseca e Silva, Livestock Science 200, 76-79 (2017) https://doi.org/10.1016/j.livsci.2017.04.011

9. A. Barbieri, R.K. Ono, L.L. Cursino, M.M. Farah, M.P. Pires, T.S. Bertipaglia, A.V. Pires, L. Cavani, O.D. Carreño, R. Fonseca, Poult. Sci. 94, 169-171 (2015) https://doi.org/10.3382/ps/peu062

10. L.P. Silva, J.C. Ribeiro, A.C. Crispim, F.G. Silva, C.M. Bonafe, F.F. Silva, R.A. Torres, Livest. Sci. 153, 27-32 (2013) https://doi.org/10.1016/j.livsci.2013.01.014

11. K. Zhu, X. Xu, D. Sun, J. Tang, Y. Zhang, Anim. Feed Sci. Technol. 190, 87-94 (2014) https://doi.org/10.1016/j.anifeedsci.2014.01.014

12. E. Bonos, E. Christaki, A. Abrahim, N. Soultos, P. Florou-Paneri, Anaerobe 17, 436439 (2011) https://doi.org/10.1016/j.anaerobe.2011.05.006

13. http://registru.ansa.gov.md/ro/content/bio-acid-ultra-acidifiant

14. A.D. Markazi, A. Luoma, Journal of Applied Poultry Research 28, 919-929 (2019) https://doi.org/10.3382/japr/pfz053 